Geosistemy perehodnykh zon = Geosystems of Transition Zones / Геосистемы переходных зон

Content is available under the Creative Commons Attribution 4.0 International License (CC BY 4.0)

2021, vol. 5, No. 2, pp. 113-127

URL: http://journal.imgg.ru/archive.html ; https://elibrary.ru/title about.asp?id=64191

https://doi.org/10.30730/gtrz.2021.5.2.113-120.121-127

\title{
The March 25, 2020 Mw 7.5 Paramushir earthquake
}

Alexander S. Prytkov*, https://orcid.org/0000-0003-4488-1682, a.prytkov@imgg.ru

Nikolay F. Vasilenko, https://orcid.org/0000-0003-1591-9071, n.vasilenko@imgg.ru

Institute of Marine Geology and Geophysics, FEB RAS, Yuzhno-Sakhalinsk, Russia

Abstract PDF ENG Резюме $\underline{\text { PDF RUS }} \quad$ Full text $\underline{\text { PDF RUS \& ENG }}$

Abstract. The strong earthquake with moment magnitude $M w=7.5$ occurred on March 25, 2020, in the North Kurils to the southeast of the Paramushir Island. The hypocenter of the earthquake was located under the oceanic rise of deep-sea trench in the subducting Pacific lithospheric plate. This earthquake has been the strongest seismic event since 1900 for an area about $800 \mathrm{~km}$ long of the outer rise of the trench. It also was the strongest earthquake for the 300-kilometer long area of the Kuril-Kamchatka subduction zone adjacent to the epicenter. The article summarizes the data on the Paramushir earthquake. Tectonic position of the earthquake, source parameters, features of the aftershock process development, as well as coseismic displacement of the nearest continuous GNSS station are considered. The performed analysis did not allow us to clearly determine the rupture plane in the source. Nevertheless, the study of the features of the outer-rise earthquake is a matter of scientific interest, since the stress state of the bending area of the subducting Pacific lithospheric plate reflects the interplate interaction in the subduction zone.

Keywords:

North Kurils, Paramushir earthquake, aftershocks, focal mechanism, coseismic displacements

For citation: Prytkov A.S., Vasilenko N.F. The March 25, 2020 Mw 7.5 Paramushir earthquake. Geosistemy perehodnykh zon = Geosystems of Transition Zones, 2021, vol. 5, no. 2, pp. 113-127. (In Russ. \& Engl.). https://doi.org/10.30730/gtrz.2021.5.2.113-120.121-127

Для цитирования: Прытков А.С., Василенко Н.Ф. Парамуширское землетрясение 25 марта 2020 г. Мw = 7.5. Геосистемы переходных зон, 2021, т. 5, № 2, c. 113-127. https://doi.org/10.30730/gtrz.2021.5.2.113-120.121-127

\section{References}

1. Ammon C.J., Kanamori H., Lay T. 2008. A great earthquake doublet and seismic stress transfer cycle in the central Kuril Islands. Nature, 451(7178): 561-565. https://doi.org/10.1038/nature06521

2. Bath M. 1965. Lateral inhomogeneities of the upper mantle. Tectonophysics, 2(6): 483-514. https://doi.org/10.1016/00401951(65)90003-X

3. Blaser L., Kruger F., Ohmberger M., Scherbaum F. 2010. Scaling relations of earthquake source parameter estimates with special focus on subduction environment. Bull. of the Seismological Society of America, 100(6): 2914-2926. http://dx.doi.org/10.1785/0120100111

4. Catalogue of earthquake focal mechanisms for Kamchatka and the Commander Islands. URL: http://sdis.emsd.ru/info/earthquakes/mechanism.php (accessed 16.01.2021).

5. Christensen D.H., Ruff L.J. 1988. Seismic coupling and outer rise earthquakes. J. of Geophysical Research, 93(B11): 13421-13444. https://doi.org/10.1029/jb093ib11p13421

6. Dach R., Lutz S., Walser P., Fridez P. (eds) 2015. Bernese GNSS Software Version 5.2. Bern: University of Bern, Bern Open Publ., 862 p. doi:10.7892/boris.72297

7. Degterev A.V., Chibisova M.V. 2020. Activation of the Ebeko volcano in May-July, 2020 (Paramushir Island, Northern Kuril Islands). Geosistemy perehodnykh zon = Geosystems of Transition Zones, 4(4): 500-505. (In Russ., abstr. in Engl.). https://doi.org/10.30730/gtrz.2020.4.4.500-505

8. Earthquakes Catalogue for Kamchatka and the Commander Islands (1962-present). URL: http://sdis.emsd.ru/info/earthquakes/catalogue.php (accessed 16.01.2021).

9. Korolev Yu.P., Korolev P.Yu. 2020. Simulation of the process of short-term forecasting of the 25.03.2020 Onekotan tsunami. Geosistemy perehodnykh zon = Geosystems of Transition Zones, 4(2): 259-265. (In Russ., abstr. in Engl.). https://doi.org/10.30730/gtrz.2020.4.2.259-265

10. Levina V.I., Lander A.V., Mityushkina S.V., Chebrova A.Y. 2013. The seismicity of the Kamchatka region: 1962-2011. J. of Volcanology and Seismology, 7(1): 37-57. https://doi.org/10.1134/S0742046313010053

11. Safonov D.A., Konovalov A.V., Zlobin T.K. 2015. The Urup Earthquake sequence of 2012-2013. J. of Volcanology and Seismology, 9(6): 402-411. https://doi.org/10.1134/S074204631506007X

12. Safonov D.A., Kostylev D.V., Fokina T.A., Kovalenko N.S. 2020. Seismicity of the South Far East of Russia in 2019. Geosistemy perehodnykh zon = Geosystems of Transition Zones, 4(2): 146-159. (In Russ., abstr. in Engl.). https://doi.org/10.30730/gtrz.2020.4.2.146-159

13. Tarakanov R.Z., Andreeva M.Yu. 2012. Role of seismic focal zone in the formation and development of the Kuril - the Sea of Okhotsk region structures. Russian J. of Pacific Geology, 31(6): 87-96. (In Russ.). 
14. Tikhonov I.N., Vasilenko N.F., Zolotukhin D.E., Ivelskaya T.N., Poplavskii A.A., Prytkov A.S., Spirin A.I. 2008. Simushir Earthquakes and Tsunami of November 15, 2006, and January 13, 2007. Russian J. of Pacific Geology, (2)1: 1-14.

15. Okada Y. 1985. Surface deformation due to shear and tensile faults in a half-space. Bull. of the Seismological Society of America, 75(4): 1135-1154.

16. Omori F. 1894. On the aftershocks of earthquakes. J. of the College of Science, Imperial University of Tokyo, 7: 111-200.

17. Shcherbakov R., Turcotte D.L. 2004. A modified form of Bath's law. Bull. of the Seismological Society of America, 94(5): 1968-1975. https://pubs.geoscienceworld.org/ssa/bssa/article-abstract/94/5/1968/121045/A-Modified-Form-of-Ba-th-sLaw?redirectedFrom=fulltext

18. Skarlatoudis A.A., Somerville P.G., Thio H.K. 2016. Source-scaling relations of interface subduction earthquakes for strong ground motion and tsunami simulation. Bull. of the Seismological Society of America, 106(4): 1652-1662. http://dx.doi.org/10.1785/0120150320

19. Steblov G.M., Kogan M.G., Levin B.V., Vasilenko N.F., Prytkov A.S., Frolov D.I. 2008. Spatially linked asperities of the 2006-2007 great Kuril earthquakes revealed by GPS. Geophysical Research Letters, 35(22): L22306. http://dx.doi.org/10.1029/2008GL035572

20. Ye L., Lay T., Kanamori H. 2021. The 25 March 2020 Mw7.5 Paramushir, northern Kuril Islands earthquake and major (Mw 2 7.0) near-trench intraplate compressional faulting. Earth and Planetary Science Letters, 556(B11): 116728. https://doi.org/10.1016/i.epsl.2020 